\title{
Mirosław Chaberek
}

University of Gdańsk

e-mail: miroslaw.chaberek@ug.edu.pl

ORCID: 0000-0002-4387-3544

\section{Cezary Mańkowski}

University of Gdańsk

e-mail: ekocm@ug.edu.pl

ORCID: 0000-0001-5496-0507

\section{A METHODOLOGICAL APPROACH TO MODELLING NATIONAL INPUT-OUTPUT LOGISTICS FLOWS}

\section{METODOLOGICZNE PODEJŚCIE DO MODELOWANIA KRAJOWYCH MIĘDZYGALĘZIOWYCH PRZEPLYWÓW LOGISTYCZNYCH}

DOI: $10.15611 / p n .2019 .12 .14$

JEL Classification: R15

Summary: The effective management of logistics flows requires the right methodology and tools, which can be used on all managerial levels, including national. In particular, in the aspect of the real problem of increase of the effectiveness of Poland's logistics system, it is necessary to develop a model of macro-logistics flows as a managerial tool to all its decision-makers. This real problem initiates scientific questions of a methodological character, in particular how to model the national input-output logistics flows, how to construct such a model, and some more general issues regarding the national logistics system, its aims and structure, if the model and modelling are assumed to be core management elements of the system. Thus, the national input-output logistics flows are the object of research, which is aimed to develop a model of these flows, especially in the case of the Polish economy. The above aim is carried out with the usage of the following methods: literature study, input-output table and Sankey diagram.

Keywords: management, economy, system, Sankey.

Streszczenie: Skuteczne zarządzanie przepływami logistycznymi wymaga odpowiedniej metodologii i narzędzi, z których można korzystać na wszystkich poziomach zarządzania, w tym na poziomie krajowym. Zwłaszcza w aspekcie problemu zwiększenia efektywności polskiego systemu logistycznego konieczne jest opracowanie modelu przepływów makrologistycznych jako narzędzia zarządzania nimi przez decydentów. Ten problem rodzi pytania naukowe o charakterze metodologicznym - przede wszystkim, jak modelować krajowe międzygałęziowe przepływy logistyczne, jak zbudować taki model oraz niektóre bardziej 
ogólne kwestie dotyczące krajowego systemu logistycznego, jego celów i struktury, jeżeli zakłada się, że model i modelowanie stanowią podstawowe elementy zarządzania tym systemem. Zatem w niniejszym artykule przyjmuje się krajowe międzygałęziowe przepływy logistyczne za przedmiot badań, które z kolei mają na celu opracowanie modelu tych przepływów, szczególnie w przypadku polskiej gospodarki. Powyższy cel jest realizowany za pomocą następujących metod badawczych: studium literatury, tabeli przepływów międzygałęziowych oraz diagramu Sankeya.

Słowa kluczowe: zarządzanie, ekonomia, system, Sankey.

\section{Introduction}

The logistics services sector is estimated to create about $6 \%$ of GDP with the dynamics to increase its sales by $8 \%$ every year (Główny Urząd Statystyczny [GUS], Tables 16, 18). With the aim to develop the competitive advantage of this sector, a logistics system, including logistics services, should be governed and managed effectively on all levels, including national. In particular, regarding the Polish economy, it is necessary to develop the right methods and tools for macro-logistics policy makers to take advantage of the country's geographical location. However, it is impossible to support them if no comprehensive, holistic map or model, which reflects the national logistics system, is developed. This problem of modelling macrologistics systems has received scant attention in the literature, and the few existing methodological approaches are still being discussed and questioned for further research. Such a situation would probably continue if it were not for the resolution of the European Parliament and the European Council, which adopted common provisions according to which a national traffic model is required as a precondition when applying for European funds for the development of national transport systems. Despite the fact that the official documents do not include the term of a logistics system, it actually refers to it, because except for transportation, the model has to include a map of infrastructure objects, and therefore also warehouse, transhipment, packing, etc. facilities, which, together with IT processes and administration, as well as maintenance, are the core of the country's logistics system. Since the logistics processes support other so-called primary economic processes, it is logical that macro-economic flows, described with input-output balance, drive macro-logistics flows, which are detailed on an operational level by a traffic model. Due to the lack of an input-output logistics model for the Polish economy in the literature, the research aim is to develop such a model, and the article's aim is to present the research results.

To meet the above research aim the following methodological procedure and methods are proposed. First, the literature is reviewed to assess the state of the art on national logistics systems to identify unexplored areas thus indicating the contribution of the research. Second, the national logistics system is taken as a modelling object to reflect its main components using a block scheme technique. 
Third, the model is detailed by a logistics input-output table, supported by Sankey diagram. Due to the usage of standard research methods, it is not necessary to provide a special methodology section, especially if the whole research is focused on finding an answer to the methodological problem of how to construct the national inputoutput logistics model.

The results of the research procedure are presented in two chapters. The first includes the structure of the national logistics system as the main methodological concept of the problem, which is then disaggregated into a logistics input-output model in the next section. The two sections are followed by a discussion and final conclusions. The expected research results, as well as the contribution of the paper to the management discipline, is a theoretical model of logistics input-out flows driven by the national economy's requirements. As the model is formulated on a relatively high level of abstraction, it falls into the class of macro-logistics models of a generic nature.

\section{Methodological approach to the identification of a national logistics system}

The study of the literature proves that probably every logistics publication touches on the problem of logistics system, its elements or element. The general problem on logistics system definition, its classification and structure in different aspects, points of view or levels have been researched and published widely in the literature (Pfohl, 2018; Blaik, 2010), therefore it is unnecessary to repeat them in this article. Instead, the national logistics system is taken as the correct object of a literature review.

The national logistics system should be classified according to the literature as a macro-logistics system, which is usually defined "(...) as a part of the economy and deals with the design of general economic flow systems. By means of laws, institutions and the creation of an optimal infrastructure, macro-logistics should enable the efficient passage of information and transportation flows." (Bücher and Sezer, 2003). A similar perception of the macro-logistics system is expressed with the next definition, according to which it can be seen "(...) as a whole of physical and information flows occurring in supply chains, whose links are entities operating within the economy of a given country (national macrologistics), the European continent (eurologistics), and even the whole world (world economy macrologistics, or global logistics) (...)" (Skowrońska, 2013). When reviewing critically the presented definitions it can be stated that the macro-logistics system can be understood as a subsystem of a national economy (the first definition) as well as a system of national economy (the second definition) at the same time, under the assumption that there are no other flows but information and real ones at supply chains and economies, which makes them equal in this perspective. Not only is the relation to the economy system discussable, but also its main activity, process or the functional scope of the macro-logistics system. For instance, the flow designing function is 
stressed in the first definition, while the physical and information flow is underlined in the second definition, which is in contradiction to the first one. In addition, these definitions do not express explicitly what is the main purpose of the macro-logistics system, they only implicitly indicate designing, creation or enabling real flows. This raises the question if the real flows are also a part of macro-logistics systems, because designing, creation or enabling are rather regulatory activities and not real. Some other misunderstandings are created by the opinions which maintain that "a systematic approach for identifying the opportunities for macrologistics changes and using them to gain corporate competitive advantage is called a macrologistics system" (Stein and Voehl, 1998), because according to this definition, a macrologistics system is functioning on a corporate level, which is in contradiction to the national level. Fortunately, there are also some authors (Banomyong et al., 2008), who see the difference between national and regional logistics systems.

Looking for other publications which could provide more in-depth study results to the above presented considerations, a working paper on national logistics systems by Dimitrov (1991) is worth reviewing first. This publication was probably the first comprehensive research on national logistics systems in six Western European countries (the UK, Sweden, the Netherlands, Japan, Finland, the USA) and six Central and East European ones (Bulgaria, Czechoslovakia, Hungary, Poland, Yugoslavia, GDR). Despite the outdated data included in the report, which reflect the national logistics systems of the above mentioned countries in the period of 1970-1988, and during the times of a centrally planned economy in the case of Poland, some issues are worth pointing out. The first is a definition of a national economy understood as "(...) material flows and stock system, which involves numerous material flows and points (economic units) of inventory formation" (Dimitrov, 1991). This definition seems to be a definition of national logistics system rather than the economic one, however it underlines the important role of logistics in the country's economy. Secondly, each of these twelve national logistics systems was analysed in two aspects: as a physical system and as an administration system. This point of view is still important and actual, because it makes clear that national logistics is not only a regulatory, managerial, coordination or integration system, but it is also a real one, especially in the form of transportation and inventory. A similar approach to conceptualising the national logistics system can be found in the publications of D. Kisperska-Moroń (1996) and M. Jacyna (2012). The former proposes to perceive the mentioned system as a set of production, trade, non-production and individual customer sectors of the national economy, linked and integrated by transportation and information processes. The proposition of the latter can be treated as an extension of the previous concept but more detailed, because the proposed model of the mentioned system consists of five kinds of output and input points, connected by transhipment points, transportation and information processes. Both propositions are a very good reflection of the real national logistics system as the self-managing, nonhierarchical systems which existed at that time. However nowadays, in addition to 
the above discussion on the macro-logistics system, its structure and relation to the economic system, the most problematic issue seems still to be the question of what is a national logistics system or how to identify it, and of what component structure it should consist. With the aim to answer these questions, the authors of the article would like to discuss their following proposition.

The foundation of every theoretical concept or practical application regarding a logistics system is constituted by the unquestionable paradigm, which maintains that every economic system (including logistics) requires to be supplied with the right resources (human, material, financial and information), in the right amount, delivered at the right place, time and cost (5R) (Chaberek, 2014; Chaberek and Mańkowski, 2017). The added value of this concept is the formulation of clear criteria for the identification of two kinds of economic systems. The first, called primary systems, need to be supplied by resources, and the second, called supportive, are aimed at supplying the first with the requested resources. Consequently, this concept also formulates clear criteria for the identification of logistics systems, mainly by giving the economic justification for starting, functioning, and finally, closing logistics systems. This clear criteria are just the resource requirements, because no resource requirement, no logistics system is needed, and vice versa. Therefore, the primary economic systems, irrespective of whether they are of a production, trade or service character, through the expression of their economic needs or requirements, determine at the same time the aims for logistics systems which are usually reflected by the above mentioned 5R criteria, or in the form of the questions: what is required, where, when, at what cost, and by how many? ${ }^{1}$ Once the aims for a logistics system are determined, the next question is about the form, about the shape, or specifically about the component structure the logistics system should consist of, to meet the aims. The general answer to this question should be looked for in the general system theory.

According to the general system theory, "a system can be defined as a complex of interacting elements" (Bertalanffy, 1968, p. 55). For most applications of this general theory it is sufficient to distinguish two categories of the system: complex (wholeness) and elements, including relations. However, for highly complex social or economic systems, including logistics, characterized by a large amount of elements, which are parts of other elements (subsystems), which in turn depend on the other subsystems, and so on, and often related in a very sophisticated way, a perception of a system as a holon is proposed. According to holonism, which originally referred to biological organisms, "the organism is to be regarded as a multi-levelled hierarchy of semi-autonomous sub-wholes, branching into sub-wholes of a lower order, and so on. Sub-wholes on any level of the hierarchy are referred to as holons. (...) Biological holons are self-regulating open systems which display both the autonomous properties

1 That is an example of how other management methods can be applied to determine resources requirements for logistics systems, as for instance: $5 \mathrm{~W}, 5 \mathrm{~W} 2 \mathrm{H}$ (who, what, where, when, why, how, how much). 
of wholes and the dependent properties of parts. (...) The term 'equilibrium' in a hierarchic system does not refer to relations between parts on the same level, but to the relation between part and whole (the whole being represented by the agency which controls the part from the next higher level)"(Koestler, 1969). When applying this approach to logistics systems, it can be stated that in addition to the previously cited definitions of a logistics system, especially from the system structure point of view, it can be defined as a holon, which is a self-controlled whole and a semicontrolled part at the same time, because as a whole it consists of parts (elements, subsystems), thus related to them, and as a part or subsystem of a higher order system (i.e. system of a company, supply chain, national economy, EU economy, etc.), thus related to them. The originality of this approach lies in the proposition that the logistics system is not perceived as an isolated object, but as a related object, which controls its parts and is controlled by a system of a higher level. Therefore, in addition to the previously mentioned logistics service support of primary economic processes and a holon structure of the logistics systems, this controlling or regulatory nature of logistics systems (including integration and coordination functions) stands for the next criteria for their identification, especially on national level. Usually, the regulatory tools are identified with legislative regulations; however they can be also social, political, economic, technological or environmental means. On the national level, the main real regulatory means which justify the being of logistics systems, are of an economic character in the form of the aggregated, inter-branches, input-output resource requirements. Since logistics is the only way to supply them, therefore the national logistics system can by identified as a holon, which supplies every economic system with resources according to the country's input-output requirements.

In searching for the national logistics systems, the proposition of TRIMODE and ASTRA transportation models were found (Figure 1). Even if they are not named formally as logistics ones, they seem to be the most advanced and matched to the above mentioned definition. TRIMODE is a complex transportation network model, used by the European Commission for the assessment of major transport infrastructure projects as well as a wide range of transport policies. TRIMODE integrates three main components:

1. A transport model, which simulates freight as well as passenger transport activity for EU28 and neighbouring countries.

2. An economy model, which describes the macro-economic development of several economy sectors for EU countries and neighbouring states, and also provides background conditions influencing transport demand generation (e.g. population, intra-regional trade) and evaluate influence of policy on regional and national economy.

3. An energy model, which estimates the dynamic of vehicle fleets and their impact on energy consumption, polluting emissions, noise, greenhouse gas, emissions, and safety. 

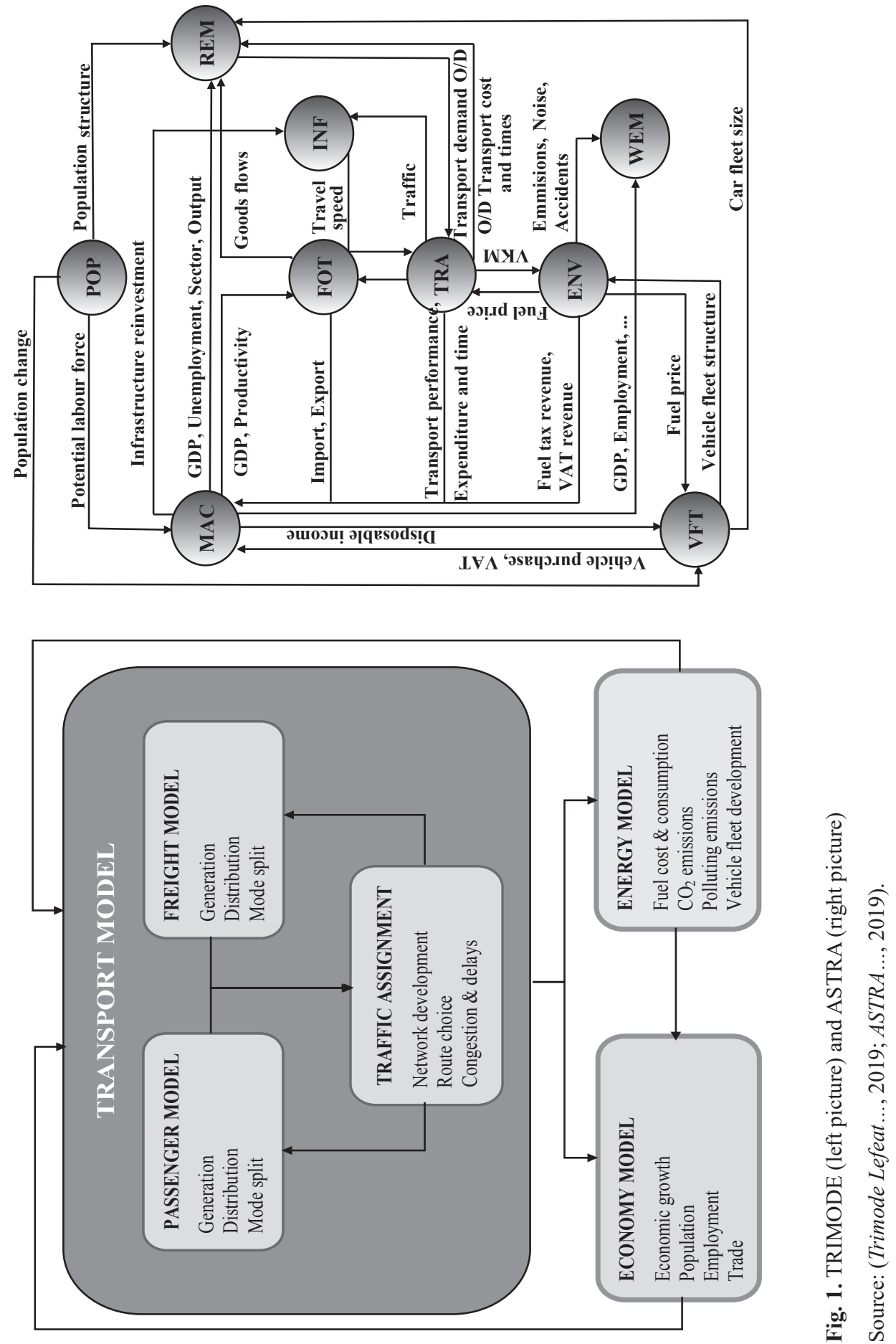
This model was prepared with PTV Visum software and is planned to operate until 2050.

ASTRA is described as an integrated assessment model, which is applied for strategic policy assessment in the transport and energy field for European Union countries. Its structure consists of nine modules: population (POP), macro-economic (MAC), regional economic (REM), foreign trade (FOT), infrastructure (INF), transport (TRA), environment (ENV), vehicle fleet (VFT), and welfare measurement module (WEM). The model is built on recursive simulations following the system dynamics concept and enables running scenarios until 2050. The applied Vensim system dynamics software provides sophisticated tools for sensitivity analyses.

Assessing the above presented models it should be stated that both of them were huge European Commission projects with large financial budgets in millions of Euro, carried out over almost three years, in the case of Trimode and ten years in case of Astra, by international project teams of academic and professional organisations. Due to the EU project realisation procedures the projects have to be good professional tools, which meet the required functionalities and other results. However, if they are indeed so good and cover all EU countries, including Poland, it is reasonable to ask a question: why is a national logistics or transportation model for Poland and other countries, such as Czechia or Slovakia, still required by EU to be elaborated? This question was asked on an expert panel in the Polish governmental organization, called the Centre for EU Transport Projects, which governs national logistics and transportation projects financed by EU (Modelling, 2019). In response, it was said that the two huge EU projects were too big, that they needed more detailed national maps or traffic models for every EU country which would like to apply for funds to make an investment in its transportation network in the next financial horizon of 2021-2027. Thus the authors of the article would like to put forward the following model of a national logistics system, obviously with the aim to be applied by the Polish government.

The proposed model of the national logistics support system is intended to be a hierarchical set of three holons, named as presented in Figure 2, however, not to leave the model simplistic, the following specification is added. Based on the previously mentioned assumption that every logistics system serves the primary system with the required resources, the first macro-economic holon is responsible mainly for running an input-output balance to reflect the national resources flow in economic terms and in real time, especially for traceability purposes and to make forecasts. It is worth saying that this task or function is not only the primary but also of ultimate importance, because the quality of received data on the country's resources needs are crucial for macrologistics decisions. Next, the macro-economic input-output balance is transformed into a macro-logistics input-output table and Sankey diagram by the second holon. Finally, the macro-logistics flows tables are sent as an input to the third holon to specify them and support with operational data, which together enable to produce an output in the form of transportation tasks. 


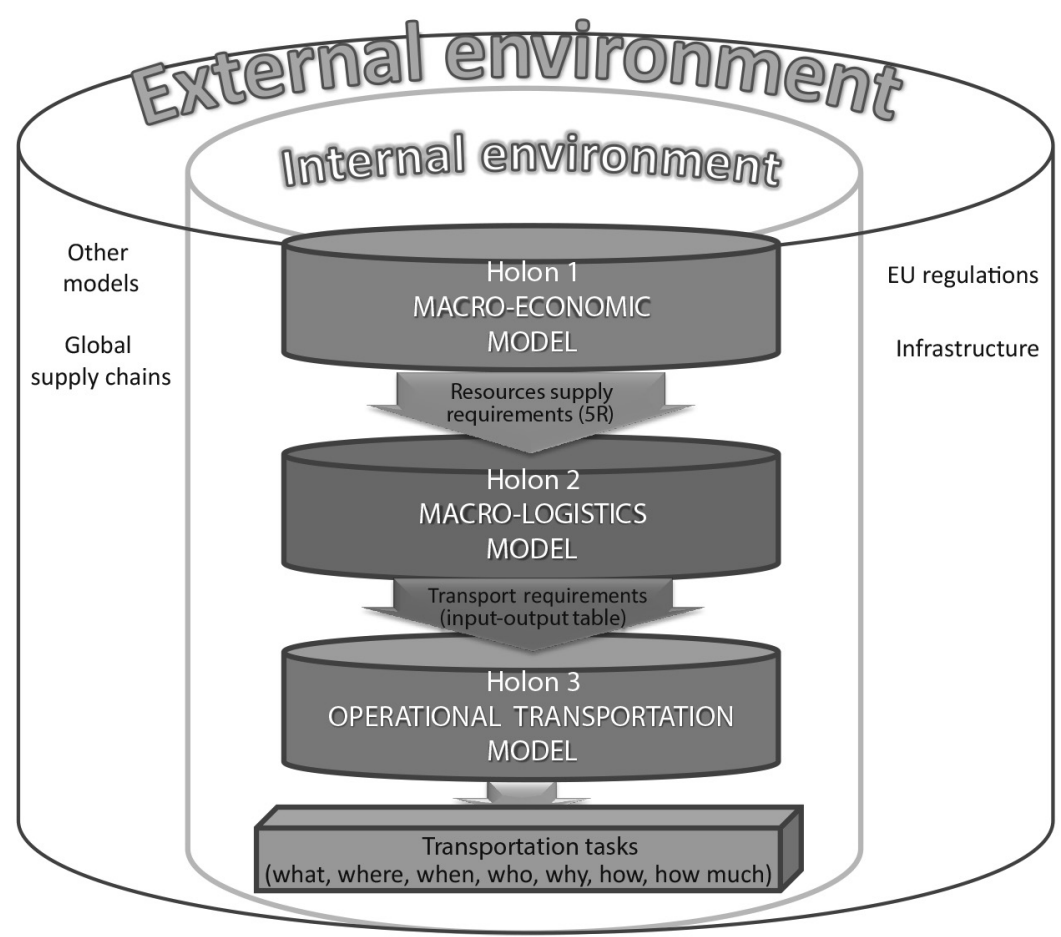

Fig. 2. Model of a national logistics system

Source: own elaboration.

Naturally, a more detailed description of this model can be constructed, however taking into account the aim of this paper, the authors would like to focus on the second holon, especially on explaining the methodology of modelling national input-output logistics flows.

\section{Modelling methodology for the national input-output logistics flows}

"An input-output table describes the flow of goods and services between all the individual sectors of a national economy over a stated period of time, say, a year" (Leontief, 1986). The above cited definition of an input-output table, which can be easily extended to definitions of an input-output model or analysis, comes from its inventor W. Leontief, who published the first input-output tables for the economy of the USA in 1941, and was awarded the Nobel Prize in economic sciences in 1973 (Garfield, 1986). From that time, input-output issues have attracted international interest, which resulted in many publications on input-output economics (Raa, 2006; Dietzenbacher and Lahr, 2004). 
In contrast to the rich economic literature, the input-output concept has received scant attention in the logistics sub-discipline. There are only a few articles which deal with that problem. For instance, the input-output tables are applied to:

- measure logistics input (costs of labour, material, capital) and output (quantity, time, place and quality) (van der Meulen and Spijkerman, 1985),

- model global and local supply chain to give managers a tool for technological and economical changes (Albino, Izzob, and Kuhtz, 2002),

- manage logistics flows through enterprise input-output models (Albino, Petruzzelli, and Okogbaa, 2008),

- prove the high impact of logistics infrastructure investment on regional economic development (Dai and Jang, 2013).

Hence there is an unexplored research area for making a contribution to the logistics sub-discipline with the application of input-output tables to reflect national macro-logistics flows according to the model of a national logistics system (Figure 2).

The proposed methodology approach to modelling the national input-output logistics flows includes the following steps:

- identification of a national economic input - output balance,

- transformation of the national economic input - output balance into the national macro-logistics input - output table,

- construction of Sankey diagram.

The national economic input-output balance is a kind of matrix table, in which the rows present a list of products as an output of economy sectors (industries, branches), and the columns also include the same list of products, but as an input to economy sectors usually in terms of money spent per one year. Despite the fact the names of industries are not listed in the table explicitly, they are clearly understood implicitly, e.g. products of agriculture and hunting are output of, or input to, the agriculture and hunting sector or branch. In the case of Polish economy, all the products are organised in the $77 \times 77$ economy products/sectors matrix and classified according to CPA 2008 (Classification of Products by Activity, 2008). These products are valued by the category of intermediate consumption (without VAT), which is measured in currency units, which in turn allows to interpret the table also as a usage or consumption balance. For instance, products of forestry flowed from the forestry industry (output) into (or were used by) the agriculture and hunting industry (input) at the value of 53924 thousand PLN, and into the forestry industry (the so-called internal or inside-branch flow) at the value of 3197124 thousand PLN in $2015^{2}$, and so on (Table 1). Based on these data, the input-output balance reflects not only the production and usage of products, needed mainly by macro-economy

2 The most recent available data on input-output balance are for 2015. It is difficult, or rather not necessary to perform a more actual research by an academic researcher or even a group of them, if there is a governmental organisation, Statistics Poland, which is responsible for this, and which has the right methodology and other resources to do so. 
policy, but also covers some information on national materials flow requirements, which are necessary to determine the aims of macro-logistics system. Returning to the $5 \mathrm{R}$ or $5 \mathrm{~W} 2 \mathrm{H}$ concept of logistics aims, this input-output balance gives the data to determine two macro-logistics aims:

- what products are the right objects of the flow,

- where the products should be supplied, i.e. from what industry into what industry ${ }^{3}$.

However, to transform the above economic input-output balance into a logistics input-output table and Sankey's scheme, the answer to the question about the next logistics objective, how many (or the right quantity) in terms of volume, has to be found.

The information about the flow of goods in terms of volume is included in the transportation tables. In analysing the data in Table 2 in comparison to Table 1, some methodological problems appeared. First, the data on transportation volume in tonnes and tonne-kilometres are ordered according to transportation modes, not according to products. Some other transportation statistics ordered by products were found, however their classification of goods is not conducted according to CPA 2008 as in Table 1. Second, even if the transportation statistics ordered by products are to be used, they do not contain information about what industry the products are coming from and what industry they are going to. This information is included in Table 1, but with no data about the volume. Thus, the proposition to solve the problems is to combine the data from Table 1 and Table 2, by calculating the products' usage coefficients (Table 1) based on the following methodological assumption: if the products were produced by one industry and used by another industry, therefore they had to be transported, no matter by what transportation mode. Thus the products' usage coefficients can be applied to calculate the transportation volume by tonnes and tonne-kilometres, unfortunately without the selection of transportation modes due to incompatible classification of goods.

The results of the research according to the above methodology are presented in Table 3 . The structure of the table is slightly changed to make clear what products and how many are coming from which industry, and to which industry they go to. First, the product's usage coefficient is calculated as its value percentage share at the value of all products required by the industry. For instance, if the value of 10010 thousand PLN of agriculture and hunting products, required by the fishing industry from the agriculture and hunting industry, is divided by 238579 thousand PLN of the total products needed by the fishing branch, then the products of agriculture and hunting usage coefficient $4,20 \%{ }^{4}$ is calculated (Table 3 ). The same

${ }^{3}$ Of course, the input-output table informs also about the value of products, what seems that it could be used to determine the third macro-logistics aim, the right aggregated cost/price of logistics services, however it can be done not explicitly, but implicitly, as one of many logistics cost/price determinants.

${ }^{4}$ Decimal numbers in Polish are written with a comma. 


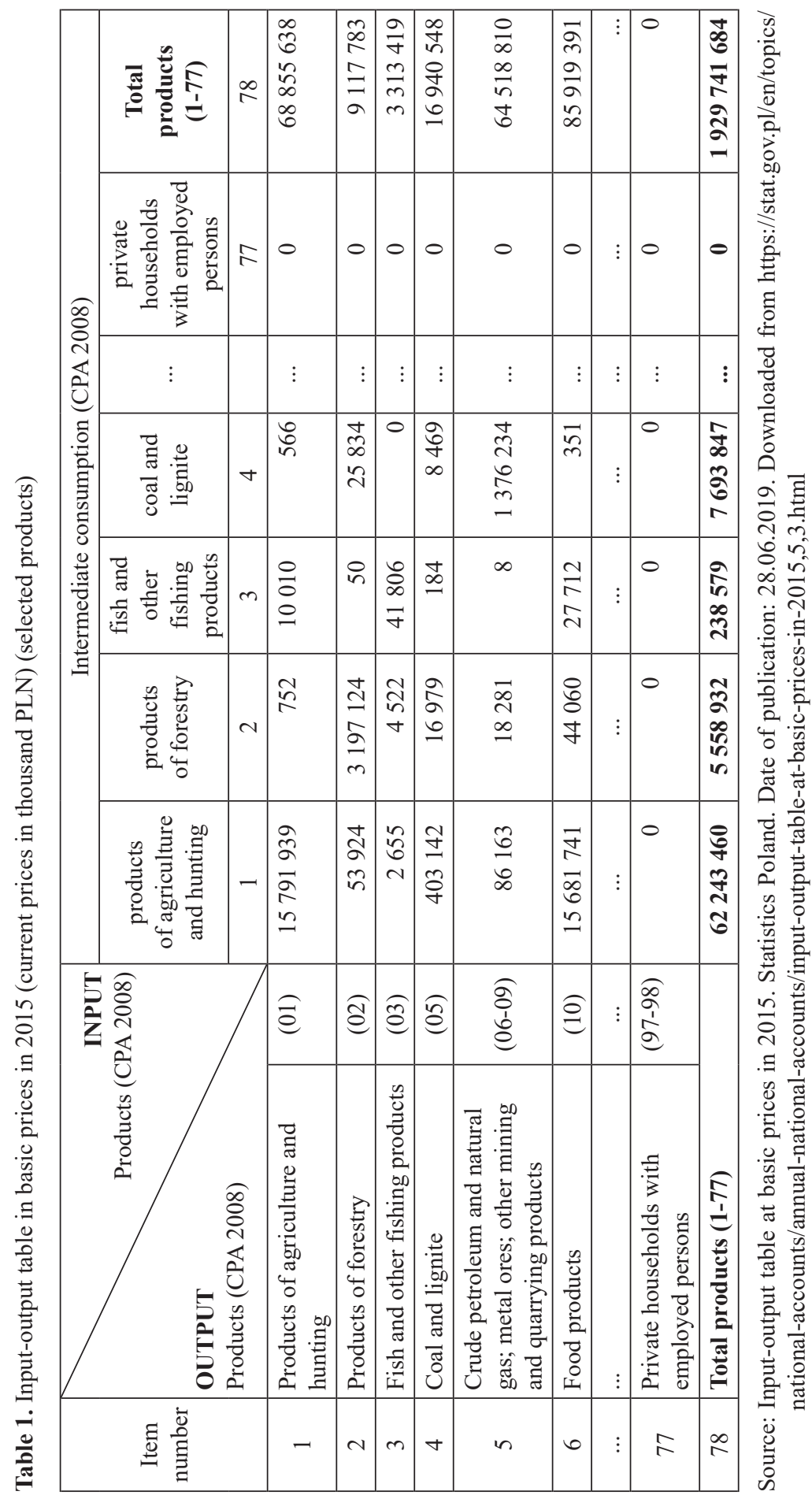


Table 2. Transportation of goods by transport mode in $2017^{*}$

\begin{tabular}{|l|r|r|r|r|r|r|}
\hline \multirow{2}{*}{ Modes of transport } & \multicolumn{3}{|c|}{ Tonnes } & \multicolumn{3}{c|}{ Tonne-kilometres } \\
\cline { 2 - 7 } & thousand & $2016=100$ & in percent & million & $2016=100$ & in percent \\
\hline TOTAL & $\mathbf{2} \mathbf{0 5 3} \mathbf{2 4 5}$ & $\mathbf{1 1 1 , 8}$ & $\mathbf{1 0 0 , 0}$ & $\mathbf{4 3 4} \mathbf{9 3 2}$ & $\mathbf{1 1 2 , 8}$ & $\mathbf{1 0 0 , 0}$ \\
\hline Railway transport & 239501 & 107,6 & 11,7 & 54797,3 & 108,2 & 12,6 \\
\hline Road transport & 1747266 & 113,0 & 85,1 & 348559,0 & 114,8 & 80,1 \\
\hline Air transport & 53 & 129,3 & 0,0 & 256,6 & 134,8 & 0,1 \\
\hline Pipeline transport & 52393 & 96,9 & 2,5 & 21079,6 & 94,9 & 4,8 \\
\hline Inland waterway transport & 5778 & 93,0 & 0,3 & 877,3 & 105,4 & 0,2 \\
\hline Maritime transport & 8254 & 113,9 & 0,4 & 9362,4 & 113,6 & 2,2 \\
\hline
\end{tabular}

* Decimal numbers in Polish are written with a comma.

Source: Statistics Poland. Downloaded from https://stat.gov.p1/en/topics/transport-and-communications/transport/transport-activity-results-in-2017,6,13.html

method was used to count the usage coefficient for the other products. Since the transportation work in Table 3 is presented in total volume for all products, it is not appropriate to multiply the individual products usage coefficient by the transportation total tonnage and tonne-kilometres directly, as first the total products value of one branch had to be divided by the total value of all branches' products to obtain the branch usage coefficient, e.g. 238579 thousand PLN divided by 1 929741684 thousand PLN, which gives the coefficient around 0,01\%. Next, the coefficient was multiplied by the total transportation volume of 2053245 thousand tonnes (Table 2) to give 254 thousand tonnes (Table 3) of total products delivered to the fishery industry, and 54 million tonne-kilometres (Table 3 ) of transportation work performed on these products, if multiplied by the total of 434932 million tonne-kilometres (Table 2), respectively. To calculate the individual products' transportation volume, for instance for the agriculture and hunting goods used by the fishery industry, the coefficient $4,20 \%$ is multiplied by 254 thousand tonnes and 54 million tonne-kilometres respectively, to obtain the volume of 3073,85 thousand tonnes and 651,12 mil. tonne-kilometres of agriculture and hunting goods delivered from the agriculture and hunting industry to the fishing industry. In the same way the volumes of products for the other industries are found.

The above presented methodology approach to construct the national input-output logistics flows table can be also useful to make a Sankey's diagram of the flows (Figure 3). This figure is a graphical representation of the nodes and relations between them. In the case of a national economy, the nodes are economy sectors with a double role, i.e. as an object of output as well as an object of input, which are related by products' flows measured in the volume terms of tonnes and tonnekilometres. The flows of products between five selected economy sectors, which are presented in Figure 3, give a preliminary knowledge on the complexity of the Polish inter-industry logistics flows for 77 industries. 


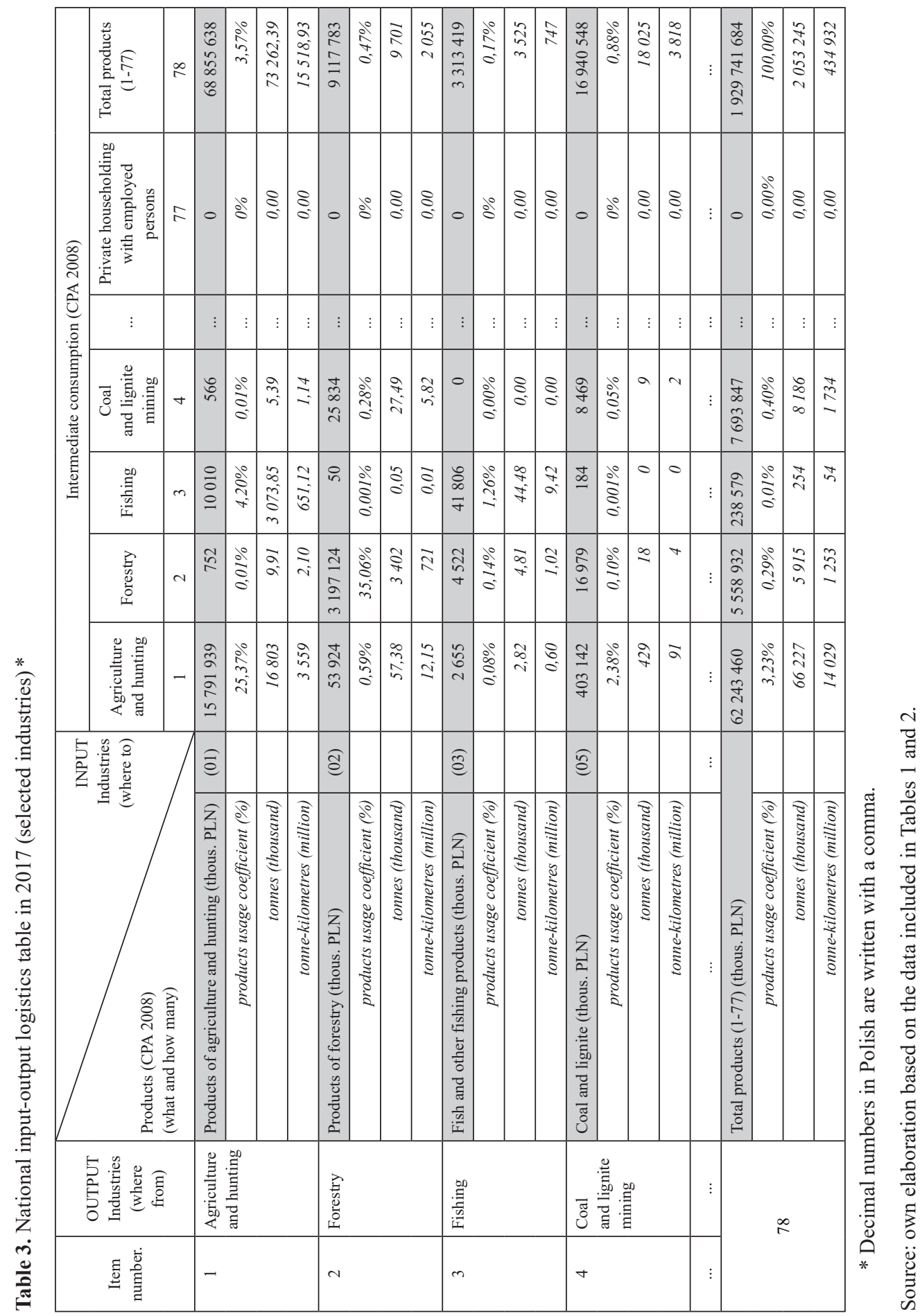




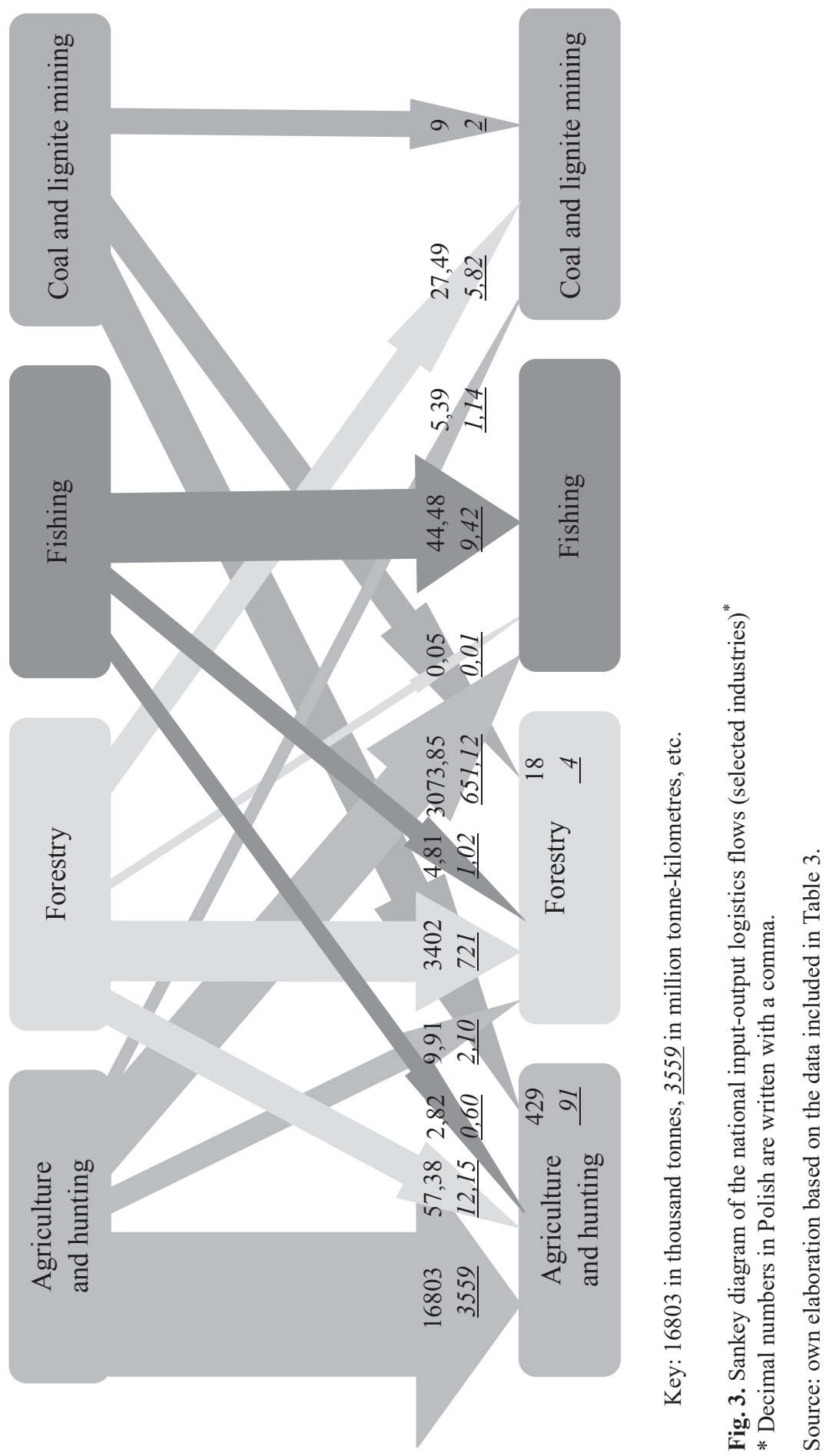




\section{Discussion and conclusion}

It seems that there should not be necessary to have a discussion on the problem whether a national economy, for instance Poland's, needs a national logistics system. Nevertheless, some opinions questioning this view can be still found. Most likely they come from not understanding the supportive, service oriented function of logistics processes, without which the other primary economic processes would not be able to run. However, even in the case where a consensus on the viable role of logistics systems is achieved, a lot of issues regarding the methods and tools to be used to manage the logistics systems effectively are discussed.

This paper discusses and promotes the result of modelling methods and tools in the form of a national input-output logistics flow model, which is rather not questioned in the theory, according to which modelling techniques are necessary instruments used in every management activities, mainly for planning, organising and controlling purposes, very often on a daily basis. The opposite attitude to modelling methods, tools and their results can however be found in business practice, which sometimes formulates questions of what are the models and what is modelling useful for. Much more doubt is expressed by economy policy makers, who if not supported by a government decision centre on national logistics system, do not see the need to elaborate a macro-logistics model of input-output flows in the economy for the purposes of their decisions, mainly regarding infrastructure investments and governmental support of the country's logistics service sector development. With the aim to answer these questions the model proposed in this paper was elaborated. From practical point of view this model also serves to convince the country's policy makers that it is possible to make real decisions regarding the implementation of the model. Thus the authors would also like to formulate the following proposals for the use of the presented model in the future. Namely, the model should be specified with the updated statistical data on interindustry flow provided by Statistics Poland, and then supported by a traffic model, which should include at least four sub-modules of what is transported, from where to where, in which way, and with the usage of which resources.

Therefore, it can be concluded that the proposed methodological approach to model the national input-output logistics flows, which is still an unexplored area, will contribute to the state of the art on this topic.

\section{References}

Albino, V., Izzob, C., and Kuhtz, S. (2002). Input-output models for the analysis of a local/global supply chain. International Journal of Production Economics, (78), 119-131.

Albino, V., Petruzzelli, A. M., and Okogbaa, O. G. (2009). Managing Logistics Flows Through Enterprise Input-Output Models. 2008 IEEE International Conference on Industrial Engineering and Engineering Management, IEEM 2008, 852-856.

Banomyong, R. et al. (2008). Formulating regional logistics development policy: The case of ASEAN. International Journal of Logistics Research \& Applications, 11(5), 359-379. DOI: 10.1080/ 13675560802389114 
Blaik, P. (2010). Logistyka. Koncepcja zintegrowanego zarządzania. Warszawa: PWE.

Bertalanffy, L (1968). General system theory. Foundations, development, applications, New York: George Brazillier, Inc.

Bücher, J., and Sezer, M. (2003). Alternative Lösungsansätze für die Distributionslogistik am Beispiel des Onlinelebensmitteleinzelhandels, Münster: LIT Verlag.

Chaberek, M. (2014). Theoretical, regulatory and practical implications of logistics, LogForum, 10(1), 3-12.

Chaberek, M., and Mańkowski, C. (2017). Teleological assumptions in the process of identification and evaluation of best logistics practices. Research Journal of the University of Gdańsk, Transport Economics and Logistics, (71), 7-16. DOI: 10.5604/01.3001.0010.5720

Classification of Products by Activity. (2008). CPA 2008 framework Regulation (EC), No. 451/2008 of the European Parliament and of the Council of 23 April 2008.

Dai, Q., and Yang, J. (2013). Input-output analysis on the contribution of logistics park construction to regional economic development. Procedia - Social and Behavioral Sciences, (96), 599-608.

Dietzenbacher, E., and Lahr, M. L. (2004). Wassily Leontief and input-output economics. New York: Cambridge University Press, 396.

Dimitrov, P. (1991). National logistics systems, collaborative paper CP-91-006, IIASA, Laxenburg, Austria, 12. Retrieved from http://pure.iiasa.ac.at/id/eprint/3574

Garfield, E. (1986). Wassily Leontief: Pioneer of Input-Output Analysis. Essays of an Information Scientist, (9), 272-281. Retrieved from http://www.garfield.library.upenn.edu/essays/v9p272y1986.pdf

Główny Urząd Statystyczny [GUS]. (n.d.). Statistics Poland. Quarterly national accounts of gross domestic product 2014-2018, Tables 16, 18. Retrieved from https://stat.gov.pl/en/topics/national-accounts/quarterly-national-accounts/quarterly-national-accounts-of-gross-domestic-product-20142018,4,11.html

Jacyna, M. (Ed.) (2012). System logistyczny Polski. Uwarunkowania techniczno-technologiczne komodalności transportu. Warszawa: Oficyna Wydawnicza Politechniki Warszawskiej.

Kisperska-Moron, D. (1996). System logistyczny gospodarki polskiej (Eng. Logistics system of Polish economy), Katowice: Wydawnictwo Akademii Ekonomicznej w Katowicach.

Koestler, A. (1969). Some general properties of self-regulating open hierarchic order (SOHO). In A. Koestler, J. R. Smythies (Eds.), Beyond reductionism. Attachment A, point 1.1, 1.4, 9.2. Retrieved from https://panarchy.org/koestler/holon.1969.html

Leontief, W. (1986), Input-output economics (pp. 19-20). New York: Oxford University Press.

Modelling Transportation of Goods (2019). Expert panel. Warsaw: Centre for EU Transport Projects.

Meulen van der, P., and Spijkerman, G. (1985). The logistics input-output model and its application. International Journal of Physical Distribution \& Materials Management, 15(3), 17-25.

Pfohl, Ch.-H. (2009). Logistiksysteme. Betriebswirtschaftliche Grundlagen, Berlin Heidelberg: Springer Verlag.

Raa, T. T. (2006). The Economics of Input-Output Analysis. New York: Cambridge University Press.

Skowrońska, A. (2013). Makrologistyka w polityce Unii Europejskiej. Gospodarka Materiałowa i Logistyka, 3(4).

Stein, M., Voehl, F. (1998). Macrologistics management: A catalyst for organizational change. Florida, Boca Raton: CRC Press.

\section{Internet sources}

ASTRA model structure. (2019). Retrieved form http://www.astra-model.eu/structure-overview.htm Trimode Lefeat 2018. (2019). Retrieved from http://www.trt.it/wp/wp-content/uploads/2018/05/1-TRIMODE_Leaflet_2018.pdf 